\title{
EN BUSCA DE LA JUSTICIA: LOS AGENTES DE CORTE Y CHANCILLERÍAS DE LA MESTA EN EL SIGLO XVIII
}

\author{
Fermín Marín BARRiguete \\ Departamento de Historia Moderna \\ Facultad de Geografía e Historia \\ Universidad Complutense de Madrid \\ ferminmarin@ghis.ucm.es
}

\begin{abstract}
RESUMEN
Los agentes de corte y chancillerias surgieron de las mestas locales medievales y pasaron a formar parte de la Cabaña Real a principios del siglo XVI. Fueron el resultado de la mayor actividad procesal en los diferentes tribunales y de la creciente conflictividad en el campo. El oficio no tenía las funciones bien definidas porque se vio arrastrado por las disfunciones institucionales y la oposición de las chancillerías. Los Borbones se dieron cuenta de la importancia del cargo en la recuperación de la mesta y en el desarrollo de la trashumancia y elaboraron un detallado plan para desacreditarlo, suprimir el empleo de Granada, restarle atribuciones y sólo adjudicarles asuntos internos y sin relevancia. Paulatinamente fue sustituido en sus facultades y comisiones por el procurador general de corte.
\end{abstract}

Palabras clave: agentes de corte y chancillerías, justicia, procesos, oficios, mesta, siglo XVIII.

\section{ABSTRACT}

Court and Chancellery agents arose from the medieval local Mestas (annual meeting of shepperds and owners of flocks) and became part of the Royal Cabin at the beginning of 18th Century. Those were the result of a greater processual activity in the various courts and in the fields. Such trade was not clearly defined because it was dragged by institutional flaws and the chancelleries' opposition. The Bourbon kings reinforced such post in the recovering of Mestas as well as in the development of transhumance and they penned a detailed plan to discredit it, to remove employment in Granada, to lessen its duties and to only give it irrelevant internal affairs. It was slowly substituted in its duties and errands by the Attorney General of the State.

Keywords: State and chancelleries agents, justice, trials, trade, Mesta, 18th Century.

\section{ZUSAMMENFASSUNG}

Die Vertreter bei Hof und der Kanzleien enstanden aus den mittelalterlichen örtlichen Mestas und wurden Anfang des 16. Jabrbunderts Teil der Cabaña Real. Dies war das Ergebnis einer umfangreichen juristischen Prozesstätigkeit unterschiedlicher Gerichte und den wachsenden Konflikten auf dem Land. Die Funktionen 
Fermin Marin Barriguete En busca de la justicia: los agentes de corte y chancillerías...

des Berufsstands waren nicht klar definiert, weil dieser unter den institutionellen Betriebsstörungen und der Opposition der Kanzleien zu leiden hatte. Die Bourbonen wurden sich der Bedeutung ibrer Aufgabe bei der Wiederherstellung der Mesta und der Entwicklung der Transhumanz bewusst. Sie erarbeiteten einen detallierten Plan, um diese Institution zu diskreditieren, deren Anwendung in Granada abzuschaffen, Kompetenzen abzubauen und ibr nur interne Zuständigkeiten zu erteilen, die von geringer Relevanz waren. Nach und nach wurden ibre Aufgaben und ibre Aussschüsse durch den Hofgeneralbevollmächtigten ersetzt.

Schlüsselwörter: Vertreter bei Hof, Kanzleien, Gerechtigkeit, Prozesse, Berufe, Mesta, 18. Jahrhundert.

SUMARIO. I. DIFUSOS ORÍGENES EN MEDIO DE LA CONFIGURACIÓN DE LA MESTA.--II. EL SISTEMA DE COOPTACIÓN.-III. EL PROYECTO ILUSTRADO: DESCONTROL Y DEBILIDAD PROCESAL.-IV. LAS SELECTIVAS Y MANIPULADAS COMPETENCIAS.-V. LAS DESCARNADAS ATRIBUCIONES DE LA DECADENCIA.-VI. EL SUSTITUTO: REDEFINICIÓN Y CRISIS EN LA PROCURADURÍA GENERAL DE CORTE.

\section{DIFUSOS ORÍGENES EN MEDIO DE LA CONFIGURACIÓN DE LA MESTA}

Sorprendentemente, las compilaciones legislativas de los Reyes Católicos concedieron gran relevancia a este cargo con un epígrafe específico, premonitorio del esperanzador futuro en la Cabaña Real ${ }^{1}$. Era de los pocos donde se detallaban pautas electorales, atribuciones o censuras ${ }^{2}$, consciente la monarquía de la necesidad de establecer los principios básicos de los mejor posicionados en la lucha por la discutida preeminencia de las leyes y privilegios.

Sus oscuros orígenes se hundían en los siglos altomedievales ${ }^{3}$ y posteriores ${ }^{4}$ en el entorno de las primitivas mestas locales 5 . La tradición dispo-

${ }^{1}$ Cuaderno de leyes de Mesta de 1731, AHN, Diversos, A. de Mesta, libro 297, primera parte, Confirmaciones Generales, pp. 231 y ss.

2 AHN, Diversos, A. de Mesta, libro 338, p. 195. Véase F. Marín Barriguete, «Reyes Católicos, proteccionismo real y Mesta: las Ordenanzas de 1492», en El Tratado de Tordesillas y su época, t. II, Madrid, Junta de Castilla y León, 1995, pp. 155-176.

3 Este clima socioeconómico se describe en los aún vigentes trabajos de R. PASTOR DE TOGNERI, «La lana en Castilla y León antes de la organización de la Mesta», en Los conflictos sociales en Castilla, Barcelona, Ariel, 1973, pp. 363-390, y Ch. BisCHKO, «El castellano, hombre de llanura. La explotación ganadera en el área fronteriza de La Mancha y Extremadura durante la Edad Media», en Homenaje a Vicens Vives, Barcelona, Universidad de Barcelona, 1967, pp. 201-218.

${ }^{4}$ Ch. J. Bishro, «The Andalusian Municipal Mestas in the 14th-16th Centuries: Administrative and Social Aspects», en Andalucía medieval. Actas del I Congreso de Historia de Andalucía (diciembre de 1976), vol. 1, Córdoba, Caja de Ahorros, 1978, pp. 347-374.

${ }_{5}$ Real provisión de 28 de enero de 1390, con inserción de un traslado de 1381, para que 
Fermin Marin Barriguete En busca de la justicia: los agentes de corte y chancillerías...

nía la sustanciación y sentencia de los pleitos y desavenencias en el contexto agrario y fuera de los tribunales. Se consideraba que en este ámbito de nada servía un defensor de las partes, y los intereses de un pastor quedaban suficientemente amparados por el buen juicio y honradez de los magistrados y la experiencia aportada por el resto de los hermanos:

«Los pleytos civiles, y criminales, que ante el Concejo, ò sus Alcaldes, ò Juezes vinieren, sean librados, y determinados simplemente, y solamente sabida la verdad, y no intervenga en ellos Abogado, ni Procurador, ni se presente escrito, so pena de cinco Carneros al que lo contrario hiziere, para el Concejo, Denunciador y Juez, por tercias partes. En esta misma pena, repartida como dicho es, cayga el Alcalde que lo recibiere; pero si alguna de las Partes fuere mas ignorante que la otra, y no sabe alegar su Justicia, el Acalde de su Oficio tome un Hermano, que le parezca sea su Procurador, y haga por él» ${ }^{6}$.

Después, con la creación en 1273, la Cabaña Real fusionó y catalizó las prácticas consuetudinarias donde se insertaba el espíritu democrático y comunitario. No obstante, cuando se nombraban, esos procuradores abogadores fueron el germen de los agentes de corte y chancillerías, nacidos como un oficio con tres marcos de actuación bien definidos: las juntas, la Corte y las chancillerías, a modo de ramas de un mismo tronco, en esencia con funciones y obligaciones idénticas, matizadas sólo por el carácter de sus asuntos en relación con el destinatario real o judicial.

Los titubeantes inicios y la prolongada y espontánea evolución condujeron a malformaciones congénitas de gran influencia posterior. Las primeras menciones las hallamos en los legajos y libros fiscales en referencia a los impuestos y portazgos reales diseminados a lo largo de cañadas y rutas migratorias ${ }^{7}$. Al principio, recibieron la calificación de procuradores de la Mesta, pero a finales del siglo XV se denominaron procuradores de puertos ${ }^{8}$, aunque siempre fueron meros delegados institucionales y nunca estuvieron integrados de pleno en el armazón orgánico, careciendo de voz y voto en las juntas y comisiones. El tardío origen y la provisionalidad crónica resta-

los vecinos ganaderos de la villa de Alcaraz (Albacete) puedan hacer tres mestas al año y ser hermanos de la Cabaña Real, con ganados y que pudieren hacer las tres mestas al año, sean hermanos de Mesta, AHN, Diversos, A. de Mesta, leg. 9, exp. 20.

${ }^{6}$ Cuaderno de leyes de Mesta de 1731, segunda parte, título XXIV, ley II, p. 208.

${ }^{7}$ Ibid., título XVII, pp. 175 y ss.

${ }^{8}$ J. KLeIn, La Mesta, Madrid, Alianza Editorial, 1979, pp. 42 y 69, y AHN, Diversos, A. de Mesta, libro 338, p. 196 v. 
Fermin Marin Barriguete En busca de la justicia: los agentes de corte y chancillerías...

ron protagonismo a sus actuaciones, muy importantes y ensombrecidas al estar relegados a una posición secundaria y prescindible. Habían surgido a la sombra de las disputas por el reparto de las contribuciones y su misión primaria consistía en contar los animales de cada ganadero en los puertos para el ulterior amillaramiento, labor no carente de problemas ${ }^{9}$. De esta manera, libraban a los asociados de los abusos de recaudadores corruptos y los derechos de hermandad no se cobraban hasta la presentación y aprobación en la junta general de otoño de los balances de procuración ${ }^{10}$. Los arrendatarios, con el fin de recuperar lo antes posible la inversión, aplicaban cualquier ardid con la intención de hacerse con las mejores reses o aumentar las cuotas estipuladas; comportamientos abrazados también por los funcionarios reales. Se habían multiplicado las denuncias por la elevación de las tasas, los recuentos abusivos o los nuevos estancos y, por ello, se les encomendó la vigilancia en un asunto tan crucial ${ }^{11}$.

Las peculiares funciones primigenias de este procurador demostraban ese carácter protector pastoril de leyes y personas, y la confluencia de cometidos. Encargado de la percepción de los repartimientos e igualdad en la aplicación, cumplimentaba el libro de asientos, ajustado con el del serviciador, con anotaciones del número de cabezas, pago, titularidad y fecha, mientras permanecía a diario y sin interrupción en los puertos. Amén de realizar un arqueo personal, tenía capacidad para vigilar y supervisar el abono de derechos a cobradores y serviciadores en defensa del mesteño. Dada la medular labor, rendía cuentas directamente al Concejo, entregaba el montante recaudado, hacía el cómputo general pecuario y soportaba la estricta residencia delante de escribano y testigos, no pudiendo excusarse de los llamamientos. Por lógica, con el propósito de alejar las acusaciones de corrupción y actuar con transparencia, les estaba prohibido comprar o seleccionar ganado de lo confiscado por los serviciadores, reducir cuotas, conceder aplazamientos, defraudar o asesorar a montazgueros. Las faltas y desobediencias se castigaban con la pérdida del salario, la inhabilitación absoluta y la expulsión de la hermandad.

Sin embargo, transcurrió bastante tiempo hasta que el oficio de procurador se instaló en otras facetas de la vida pastoriega para desempeñar

9 Inventario del Archivo de la Mesta, AHN, Diversos, A. de Mesta, libro 294.

${ }_{10}$ Cuaderno de leyes de Mesta de 1731, segunda parte, título XLVI, pp. 249-250, y Libros de Cuentas del Honrado Concejo de la Mesta, AHN, Diversos, A. de Mesta, libro 527.

${ }^{11}$ Cuaderno de Leyes de Mesta de 1731, primera parte, privilegio XI, p. 26; privilegio XXII, p. 54; privilegios XXXII al XXXVII, pp. 106 y ss.; privilegios XLIII y XLIV, p. 132, y privilegio LX, p. 198. 
papeles de abogadores, por ejemplo, en la Corte, evolución retrasada y lentificada por las atribuciones otorgadas a los jueces y la práctica consuetudinaria. No prosperaban en un clima adverso, que obligaba a los alcaldes a resolver querellas y satisfacer a los litigantes sin recurrir a la intervención de la Cabaña Real ${ }^{12}$. A la vez, no se respetaban los mandamientos de emisión de permisos u órdenes correspondientes, o, al menos, de informes recomendatorios de los letrados en la nominación de procuradores, y ejercían de manera clandestina con jueces especiales del Consejo de Castilla u oficios mesteños y en causas particulares de hermanos. Sin constar notificación no se preveían recursos humanos y económicos, no se pagaban gastos y costas contrarias a acuerdos y leyes, y de nada servía la advertencia de que los contraventores de la normativa abonarían los costes generados y las indemnizaciones pertinentes ${ }^{13}$.

Muy simple, confusa e incompleta fue la transposición de los procuradores de puertos a los procuradores de dehesas. Surgieron a principios del siglo Xvi por la patente escasez de hierbas, las notorias disputas por el aprovechamiento y la cruda rivalidad entre cabañiles. Se entremezclaron con los jueces especiales y los alcaldes entregadores en la defensa de los privilegios para apoyar la configuración del derecho de posesión. Sin embargo, nunca se generalizaron y su radio de actuación se redujo a las zonas pastueñas cardinales que afectaban a las grandes cabañas y a numerosos ganaderos, como el Valle de Alcudia, La Serena, los prados extremeños o los cordobeses, siendo excepcional su nombramiento en casos privativos. La representación colectiva en nombre de la Cabaña Real suponía mayores garantías de legalidad, protección y salvaguarda de preferencias, además de otras ventajas contractuales relativas a precios y condiciones aceptadas por los terratenientes. Al tiempo que evidenciaban el desamparo de medianos y pequeños pastores, no cabía duda de los beneficios reportados a los señores de rebaños, que consiguieron prebendas específicas frente al resto. En definitiva, lo

${ }^{12} \mathrm{El}$ acervo de los alcaldes de cuadrilla precisaba que jamás remitieran causa alguna al Concejo y nombrasen, en caso necesario, un hermano acompañante en el litigio: «Ningun Alcalde, ni Juez del Consejo, sea ossado de remitir pleito, que ante èl viniere al dicho Concejo, so pena de treinta Carneros; la tercia parte, para el Concejo; la otra, para la Parte, ò para quien lo acusare; la otra, para el Alcalde que lo juzgare: y mas pague à la Parte el daño, que por la dicha remision le vino; empero, si huviere duda del pleito, è no se atreviere à lo determinar, busque una persona, ò dos Hermanos del dicho Concejo; y junto con ellos determine la dicha causa como mejor pudiere, so la dicha pena: y la persona, ò personas que por el dicho Alcalde fueren nombradas, para determinar el dicho pleito, sean obligados à lo hazer, so pena de treinta Carneros, repartidos como dicho es, la qual pena pueda executar el dicho Alcalde» (ibid., título V, ley XII, p. 61).

${ }^{13}$ Ibid., título XV, ley X, p. 157. 
que en los inicios parecía un cargo fundamental en el desarrollo de la posesión fracasó por la indefinición intestina, el aislamiento institucional y la contracción de sus competencias a asuntos de pasto concretos.

Ante las carencias del Honrado Concejo, los ganaderos adoptaron, no sin coacción y descontento, la fórmula privada de la procuración para atender sus cuestiones, que agrandaba la escisión en la representatividad. La emergencia de problemas y el empeoramiento de otros provocó, al unísono, la aparición de leyes preceptivas sobre que los hermanos no residentes en sus hatos dejasen mayoral o procurador con el objetivo de solventar las quejas y pleitos ${ }^{14}$, principalmente los referentes a la posesión y los arrendadores concejiles; en caso contrario, estaba previsto que el alcalde o juez cualificado designase personero por su cuenta hasta la conclusión del juicio ${ }^{15}$. Mientras esos procuradores no destacaron en la dinámica pecuaria y participaron en un insignificante número de temas pasaron desapercibidos, pero ascendieron a protagonistas cuando se multiplicaron por el incremento de altercados pastueños y fiscales, entorpeciendo, con frecuencia, el normal ejercicio de la justicia con irregularidades y la defensa de intereses individuales. La descentralización y la negligente prevención de la Mesta había conducido a situaciones caóticas con enfrentamientos entre procuradores, disparidad de criterios legislativos, superposición de jurisdicciones, delegaciones orales o anómalas declaraciones. En un intento de regular los procedimientos, los alcaldes entregadores recibían órdenes expresas en sus comisiones de rehusar la presencia y testimonios de pretendidos agentes sin poder escrito y sellado.

En definitiva, los oscuros orígenes, las difusas y poco concretas funciones, y la impopularidad de la representación cabañil aniquilaron la oportunidad de esculpir un oficio dúctil y necesario en el metamórfico mundo agrario del cuatrocientos y del quinientos, capaz de asumir atribuciones representativas y de legitimación en la Corte y los tribunales, de tal manera que no aparecieran interrupciones u obstáculos de cualquier tipo desde el entorno pastoril e institucional hasta las distintas instancias en custodia y vivificación de las leyes y privilegios trashumantes. Los primeros resultados fueron pálidos e imprecisos empleos, precarios en el tiempo, difuminados en la forma, inconexos en sus objetivos, con comisiones fragmentadas y solapadas, y caracterizados por una evolución macilenta y confusa. A pesar del imprescindible proteccionismo regio, no se calibró la bondad de

${ }^{14}$ Ibid., título XXIV, ley VI, p. 209.

${ }^{15}$ Ibid., título XXV, leyes VIII y IX, p. 212. 
un cargo con tales facultades cortesanas, y ni siquiera se intuyó la conveniencia de la continuidad.

Hubo que esperar al reinado de los Reyes Católicos para encontrarnos los perfiles definitivos del oficio, aunque incompletos, del resto de la Edad Moderna. Se ensamblaron a la perfección en el organigrama político regio y conformaron una vía de actuación prioritaria y básica de la Cabaña Real, asignada rectora del proyecto agrario oficial. Rescataron la figura de las procuradurías medievales al modelar un cargo tripartito adaptado a las necesidades de la asociación en la Corte y los juzgados. La mesta ignoró sus propios recelos con respecto de las procuradurías y las utilizó sin pudores en la denuncia de las roturaciones y vedas en pastos comunes y dehesas, peligrosas, prolíficas y cercenadoras de la libertad de tránsito, ataques a las cañadas y vías, proliferación de impuestos o altercados en los arrendamientos. No obstante, se le dio carácter provisional y prescindible, considerando que los rompimientos, cotos y otros abusos eran un fenómeno temporal y de fácil solución por medio de la aplicación de los privilegios. No quisieron reconocer que campesinos e instituciones se habían lanzado abusivamente a la ocupación indiscriminada de pastizales e itinerarios migratorios, sin que importaran las prerrogativas cabañiles, la falta de licencias o el uso previo de los terrenos ${ }^{16}$.

El ambicioso programa agrario del Trono abarcaba la remodelación de las estructuras pecuarias locales con la intención de consolidar la jurisdicción del Honrado Concejo en un ámbito bastante hostil y discordante. Se pensó en la modulación de procuradurías municipales dependientes del procurador general concejil o de corte, a modo de ramificaciones hasta los últimos rincones de la Castilla ganadera. Así, se ordenó a los alcaldes de cuadrilla la convocatoria de mestas para nombrar procurador encargado de inspeccionar los términos y descubrir las labores y cercados fraudulentos, función ampliable a otros delitos contrarios a la trashumancia ${ }^{17}$. Sus informes y testimonios, depositados en persona en la junta general, conformaban las instrucciones de los alcaldes entregadores y demás oficios, y, en su caso, iniciaba el proceso con delegados en las chancillerías o el procurador de corte formulaba las peticiones por él al Consejo ${ }^{18}$.

${ }^{16}$ No sólo eran pastos, sino también abrevaderos, majadas y vías pecuarias. Es decir, se tendía a cerrar totalmente el término municipal para que estuviera a disposición del ayuntamiento y vecinos.

${ }_{17}$ Cuaderno de leyes de Mesta de 1731, segunda parte, título V, pp. 58 y ss.

${ }_{18} \mathrm{Ibid}$., título L, ley I, p. 253. Por supuesto, no escaseaban los apercibimientos y sancio- 
Fermin Marin Barriguete En busca de la justicia: los agentes de corte y chancillerías...

En los siglos XVI-XVII, los agentes, aunque privados de autoridad y protagonismo, se afianzaron como colaboradores habituales de la magistratura y consignatarios cortesanos en todos de asuntos pecuarios ${ }^{19}$. Parecían llamados a ocupar un conspicuo papel en la pervivencia y desarrollo trashumantes. Eran preceptivos, gestionaban, asesoraban y la Cabaña Real costeaba salario y asumía responsabilidades subsidiarias ${ }^{20}$. No obstante, las disfunciones intestinas y rígida relación con el marco institucional hicieron imposible reformas conducentes a optimizar los resultados de sus actuaciones ${ }^{21}$ y evitar irregularidades procedimentales que desembocaban en nocivos problemas y conflictos. Por ejemplo, la ausencia de procurador acarreaba, primero, fallos desfavorables en los juicios y condenas; segundo, entrañaba la insatisfactoria respuesta del rey; tercero, reforzaba el convencimiento de la desatención a los ganaderos y la falta de representatividad; cuarto, demostraba el caos administrativo y el descontrol de los oficiales; quinto, reflejaba la debilidad de la presidencia a la hora de ejecutar las ordenanzas; sexto, la autonomía diligenciera de los poderosos señores de rebaños, que solventaban solos los altercados. Sus balances jurídicos, informes o memoriales no vinculaban, pero siempre prevalecía la costumbre de aceptarlos de soporte legal en una actuación posterior, en especial si se trataba de una cuestión urgente o trascendente. Ahora bien, los años finales del seiscientos asistieron al derrumbe y descrédito de los agentes de corte y chancillerías, arrollados por la crisis institucional, la desprotección regia y las conflictivas mutaciones agrarias. Se rompieron, así, las esperanzas en el refuerzo de autoridad y en la recuperación de la prosperidad procesal.

nes de treinta carneros por omitir o contravenir las comisiones. Se hacían depender de los jueces cuadrilleros, aunque sus declaraciones fueran la base legal para reclamar el cumplimiento de los privilegios y sus argumentos los esgrimidos en otros tribunales.

${ }_{19}$ Recopilación de los mandatos, providencias y autos mandados guardar en varios concejos de la mesta celebrados desde el año 1548 hasta 1597, en razón de lo que deben observar los alcaldes entregadores, cuadrilla, procuradores de corte y chancillerías y otros ministros, AHN, Diversos, A. de Mesta, libro 328.

${ }^{20}$ Libro de poderes del Honrado Concejo de la Mesta, 1633-1636, AHN, Diversos, A. de Mesta, libro 321.

${ }^{21}$ Unos primeros avances los podemos encontrar en F. MARín BARRIgUETE, «Actividad procesal y ganadería mesteña (1480-1731): los agentes de corte y chancillerías», Documentos de Trabajo, Biblioteca Histórica Marqués de Valdecilla, Madrid, UCM, 2007, pp. 1-28. 
Fermín Marín Barriguete En busca de la justicia: los agentes de corte y chancillerías...

\section{EL SISTEMA DE COOPTACIÓN}

Los Borbones encontraron un oficio tripartito controvertido, aunque fundamental, y precisado de reformas en sus competencias y mando para ejercer con más eficacia la defensa de los ganaderos y del aparato jurídico cabañil ante los juzgados y la Corte. La trascendencia de su administración estaba fuera de duda, ya que cuando conseguía la resolución de los litigios a favor de los afectados, en multitud de ocasiones el propio Concejo publicaba leyes derivadas de súplicas y memoriales y además sentaba jurisprudencia aplicable en posteriores problemas y situaciones, engrosándose el cuerpo legislativo. Sin embargo, a mediados del siglo XvIII no había traspasado la esfera de mero gestor en los tribunales y la Corte, carecía de margen de maniobra por el férreo control y era un desdibujado burócrata; sólo el procurador general de corte había aumentado la presencia, que no el poder, en el organigrama administrativo ilustrado.

Las plazas de agentes de corte y chancillerías se cubrían por el sistema electoral ordinario de vocales en las juntas ${ }^{22}$, escogidos dos de entre los más afamados ganaderos de las cuadrillas por, en este orden, mayoría, votos y suertes, según se dieran las situaciones ${ }^{23}$, jurando actuar en conciencia y no por intereses partidistas o privados. Elegían en secreto a tres personas por cargo en los plazos previstos por la ley, y tras el sorteo, y valorados los ganadores ${ }^{24}$, se formulaba la propuesta ${ }^{25}$, sometida a aprobación por el presidente y la asamblea general ${ }^{26}$. El reglamento permitía la prórroga temporal de la anualidad hasta finalizar los mandatos y pleitos pendientes, en lógica correspondencia con sus facultades. Por supuesto, había una preselección de candidatos, versados en leyes, con experiencia gestora y reputados abogados de las prácticas de la trashumancia ${ }^{27}$; es decir, capaces de asumir y conseguir la misión de contestar a los oponentes, convencer a la Corona, preservar los ciclos trashumantes y fortalecer la hermandad. Tan ambiciosos objetivos no estaban al alcance de cualquiera y debía reunir cualidades personales y formativas nada comunes.

\footnotetext{
${ }^{22}$ Idéntico al de fiscal general, relator, escribano del libro de caja o alguacil del Concejo.

${ }^{23}$ Cuaderno de leyes de Mesta de 1731, segunda parte, título II, ley XXVIII, p. 35.

${ }^{24}$ Ibid., título II, leyes XXX y XXXI, p. 35.

${ }^{25}$ Ibid., título II, ley XXIX, p. 35.

${ }^{26}$ Ibid., adición al título II, capítulo VI, pp. 40 y 41.

27 M. A. Melón Jiménez, A. Rodríguez Grajera y A. Pérez Díaz (coords.), Extremadura y trasbumancia (siglos XVI-XX), Mérida, Editora Regional de Extremadura, 1999.
} 
Fermin Marin Barriguete En busca de la justicia: los agentes de corte y chancillerías...

Tampoco a principios del setecientos se había concretado un número suficientes de puestos en el nombramiento de agentes de corte y chancillerías. Variaban en relación con la cantidad de pleitos, la complejidad de los expedientes cortesanos abiertos o las demandas pendientes de atención; oscilaban de dos a cuatro en el mejor de los momentos, pero nunca se planteó una cifra significativa. La retracción procesal experimentada por la Mesta a lo largo de la centuria paralizó definitivamente la dotación de plazas ilimitadas, e, incluso, existía una marcada tendencia a mantener mínimos y llegar a la supresión total o parcial. Aunque sorprendente, se esperaba el Acuerdo de 13 de abril de 1739 de desaparición del agente de la chancillería de Granada con el argumento de ahorrarse salarios baldíos por «ociosos respecto del ningún trabajo que tenian, y que si pareciese à la Junta era de sentir que conforme fuesen vacando se extinguiesen estos empleos, y quedase à beneficio del Concejo sus sueldos» ${ }^{28}$. No había duda, se desamparaban los invernaderos con esa ablación injustificada en momentos de máxima conculcación de los códigos de paso y pasto, y la debacle de la posesión ${ }^{29}$. No resultaba creíble prescindir del oficio defensor en los juzgados con el argumento de innecesario por falta de litigios, sustituyéndose por procuradores especiales y temporales enviados en casos graves y urgentes o, se presumía, transformando en distrito único el reino de Castilla ${ }^{30}$. Detrás estaban la desprotección regia y el exagerado peso de las elites ganaderas con mucha influencia en círculos palaciegos, guías de la mano de los legisladores. Tenían intereses discordantes con la mayoría de los hermanos ${ }^{31}$ y la genera-

${ }_{28}$ M. BRIEVA, Colección de leyes, reales decretos y órdenes, acuerdos y circulares pertenecientes al ramo de Mesta desde el año 1729 hasta el de 1827, Madrid, Imprenta de Repullés, 1828, y AHN, Diversos, A. de Mesta, libro 301, p. 47. Se ratificó en la junta general de 21 de mayo de 1740, Acuerdos del Honrado Concejo de la Mesta, AHN, Diversos, A. de Mesta, libro 514.

${ }^{29}$ Evidente en Memorial ajustado, becho en virtud del decreto del Consejo, del expediente consultivo que pende de él, en fuerza de Real Orden comunicada por la Secretaría de Estado y del Despacho Universal de Hacienda, con fecha en San Ildefonso de 20 de julio del año de 1764, entre D. Vicente Paino y Hurtado, como diputado de las ciudades de voto en Cortes, Badajoz, Mérida, Trujillo, y su sexmo, Llerena, el Estado de Medellín y villa de Alcántara, por si y toda la provincia de Extremadura, y el Honrado Concejo de la Mesta general de estos reinos: en que intervienen los señores fiscales del Consejo y D. Pedro Manuel Sáenz de Pedroso y Ximeno, procurador general del reino. Sobre que se pongan en práctica los 17 capítulos o medios que en representación puesta en las Reales manos de S. M., propone el diputado de las ciudades y provincia de Extremadura, para fomentar en ella la Agricultura y cría de ganados, y corregir los abusos de los ganaderos trashumantes, Madrid, 1771.

${ }^{30}$ Esta hipótesis no se barajaba en la documentación, pero sí se indicaba.

31 A. GIL Soto, Deudos, parciales y consortes. Estrategias politicas y sociales de la oligarquía rural extremeña (siglos XVII y XVIII), Cáceres, Universidad de Extremdura, 2003; M. HERNÁNDEZ, «El desembarco de los nuevos mesteños en Extremadura: la venta de la dehesa de La Serena y las transformaciones de la trashumancia, 1744-1770», Historia Agraria, núm. 27 
Fermin Marin Barriguete En busca de la justicia: los agentes de corte y chancillerías...

lización de las prácticas trashumantes porque se veía perjudicada la rentabilidad de sus cabañas en cuanto la competencia mermaba las oportunidades de arrendamiento y ayudaba a la subida de los precios de las hierbas. Una ideología rupturista con el pasado que contradecía la esencia y sentido del Honrado Concejo, en intentos febriles de salvaguardar antiguos cimientos sustentadores de una estructura remodelada, ajena e insoldable.

La brusca redefinición de la política mesteña de los Borbones sólo se explicaba en el marco de un proyecto de depuración institucional, asentado sobre la convicción del excesivo número de oficios, el negligente ejercicio o la pérdida de funciones y significado de la Cabaña Real. Rodeados hasta entonces de un ejército de colaboradores privativos, sin reflejo en los reglamentos y aprobados y auditados por el Concejo, estos apoderados de corte y chancillerías debieron prescindir de asistentes expertos en tramitaciones legales y recopilaciones legislativas en la preparación y avance de las causas. La reducción de los recursos humanos y el recorte de plazas sembraron el caos legal con deficiencias, irregularidades y sobrecargas conducentes a reiterados y sonados fracasos, que desprestigiaron a los titulares e hicieron germinar las dudas sobre la continuidad del cargo, tripartito o bipartito según la fecha.

\section{EL PROYECTO ILUSTRADO: DESCONTROL Y DEBILIDAD PROCESAL}

En tal clima de oposición y crítica se ajustaron los ya lesivos mecanismos de control, pero de sentido diferente a los existentes en los siglos precedentes, donde se escudriñaban fórmulas orientadas a magnificar cometidos que relanzaran la crianza y la mesta ${ }^{32}$. En el setecientos, las medidas

(2002), pp. 65-100, e ÍD., «Señores trashumantes entre Madrid y Segovia: los Negrete», en M. A. Melón Jiménez, A. Rodríguez Grajera y A. Pérez Díaz (coords.), Extremadura y trasbumancia (siglos XVI-XX), Mérida, Editora Regional de Extremadura, 1999, pp. 55-66.

32 No había apenas diferencias con los objetivos de la reforma de 1644, que determinó responsabilidades y la metodología documental a las que estaban sujetos (Acuerdos del Honrado Concejo de la Mesta, libro 508, y Cuaderno de leyes de Mesta de 1731, segunda parte, título XV, ley XVI, p. 158). Precisaba la descripción de cada diligencia en busca de la total transparencia en residencias, ejecución de sanciones y reclamaciones, de ahí la especificación del estado de cada pleito o gestión con el fin de conocer estancamientos, olvidos, avances o estrategias recomendadas (Cuaderno de leyes de Mesta de 1731, segunda parte, adición al título XV, capítulo V, p. 162, y ley XIX, p. 159). Mucha importancia concedía la reforma a los sobreseimientos, intentados tapar por los procuradores, pues significaban sonados fracasos, casi siempre consecuencia de la negligencia de agentes y abogados, inaceptable en la 
Fermin Marin Barriguete En busca de la justicia: los agentes de corte y chancillerías...

adoptabas iban en detrimento de estos procuradores y se afanaban en la búsqueda de medios de sustitución instantánea de los ineptos y holgazanes. Obligados a presentarse en todas las juntas generales, se fiscalizaban las comisiones antecedentes, relaciones e informes depositados el primer día para la revisión por el fiscal ${ }^{33}$, riguroso censor de resultados y gestiones con el asesoramiento de los letrados y diseñador de las directrices a seguir en asuntos inconclusos, apelaciones, súplicas o fallos parciales. Se dispuso la traída a las juntas semestrales de los mandamientos facultativos anteriores de seguimiento de pleitos y expedientes ${ }^{34}$, juramento de veracidad de datos ${ }^{35}$ y la aplicación de sanciones a los contraventores ${ }^{36}$. En pocos empleos se precisaba con tal minuciosidad la exigencia de la comparecencia, la conducta y las relaciones con los otros oficiales ${ }^{37}$. La ausencia desencadenaba múltiples inconvenientes y las excusas no se aceptaban, salvo licencia del presidente ${ }^{38}$, que se encargaba de la documentación con el fin de no interferir en el desarrollo de las juntas, cada vez menos interesadas en la información judicial o etéreas posturas ilustradas ${ }^{39}$. De hecho, la fluida relación de los ganaderos y cargos concejiles con influencias y puestos en la burocracia real desembocó en trabajos más fáciles y directos, puenteándose a los agentes de corte y chancillerías. Era un signo evidente del cambio, pues ya no se consideraban cruciales sus testimonios en la

lucha por la vigencia de los privilegios de la Cabaña Real. Se requería la fabricación de un catálogo, que debía permanecer actualizado, con el asiento completo de personas, motivos, lugares, pruebas, o legislación, para revisar y recurrir las querellas trascendentes o donde se tuviera la seguridad de un cambio de táctica favorable; lo mismo se estipuló en los procesos perdidos (ibid., segunda parte, título XV, ley XX, p. 159, y ley VIII, p. 157). Por último, se daban las instrucciones a fiscales y escribanos para la formalización de las residencias y expedición de documentos acreditativos (ibid., adición al título XV, capítulo V, p. 163).

33 Ibid., segunda parte, título XIV, ley I, p. 149.

34 Ibid., título XV, ley XIII, p. 158.

35 Ibid., ley VI, p. 156.

${ }^{36}$ Ibid., segunda parte, título II, ley XXXIII, p. 36.

${ }^{37}$ Ibid., título XV, ley I, p. 155. Los documentos afirman: «Sean obligados de ir à cada uno de los Ayuntamientos, que el dicho Concejo de la Mesta hiziere, à dàr quenta de su Oficio, y de lo que han hecho, y lleven por memoria los pleitos, y negocios que han tratado, y en què estado están, por fee de el Escrivano ante quien pasan, y de lo que es necesario de hazer en los dichos pleitos [...] para que allí se provea lo que fuere menester: y ansimesmo quando se fueren, lleven por memorial las cosas que han de hazer, y dexen otro tal, firmado de su nombre, en poder de los Escrivanos del Concejo, por el qual les sea pedido quenta quando volvieren al Concejo; y si assi no lo hizieren, no les libre nada de su salario».

${ }^{38}$ En caso contrario, las leyes especificaban una multa de ocho reales por ausencia destinados a los gastos generales de la asamblea (ibid., ley XVIII, p. 159).

39 Colección de Impresos o Colección Corriente, 1567-1834, AHN, Consejos Suprimidos, libros 1473 y ss. 
Fermín Marín Barriguete En busca de la justicia: los agentes de corte y chancillerías...

futura planificación de estrategias, articulación de debates o redacción de comisiones, en teoría condicionados por los detalles aportados. No había expectación por su intervención y tampoco se recogían sus informes en los libros de actas, asentados por el escribano en los libros de agentes de corte y chancillerías $^{40}$. A partir de 1740 el agente de chancillería de Granada había sido suprimido y el de Valladolid relevado de asistencia a las juntas generales: se había eliminado la fiscalización.

Un silencio opaco rodeaba las gestiones cortesanas o los datos procesales de los pleitos llevados por la Mesta y casi nadie conocía o era imposible de averiguar la identidad de demandantes y demandados, los argumentos, los testigos, las pruebas, los veredictos o los recursos. Había empeorado la desastrosa confección de los libros registro, tenidos por poco útiles a pesar de las leyes ${ }^{41}$, transformados en legajos improvisados de anotaciones sin seriar e incompletas, a lo que contribuían el retraso de la entrega de relaciones, el habitual aplazamiento de la transcripción, los olvidos descontrolados, la temporalidad de los presidentes o el desentendimiento de los fiscales. La solución hubiera estado en la formación de una comisión permanente de seguimiento vigilante del rigor documental que estudiara y propusiera marcos de actuación en la siguiente convocatoria. Quimera imposible en medio del declive de una institución visible durante unas pocas semanas al año.

Cuando se traspasó la charnela de 1700 concluyeron prácticas de pleno aceptadas y a partir de ahora decapitadas por ofender las ideas ilustradas. Se cercenaron las instantáneas competencias de los procuradores en las causas generadas por la gestión de los alcaldes entregadores en las audiencias ${ }^{42}$. No se iba a permitir que los agentes mesteños ayudasen a esos magistrados a presionar a los campesinos con la vigencia y ejecución de anacrónicos privilegios. La legislación antecedente se declaraba obsoleta ${ }^{43}$ y se rescataban las leyes convenientes para reducir el número de litigios generados por los hermanos ${ }^{44}$. Se rasgaban las prerrogativas que colocaban a los ganaderos bajo el seguro manto protec-

${ }^{40}$ Cuaderno de leyes de Mesta de 1731, segunda parte, título XV, ley XI, p. 158.

${ }^{41}$ Ibid., título XLVIII, ley I, p. 251.

42 Sirvan de ejemplo Relaciones de alcaldes entregadores, AHN, Diversos, A. de Mesta, Partido de Cuenca, libros 468 y 469; Partido de León, libro 495; Partido de Segovia, libro 483, y Partido de Soria, libro 461.

43 Acuerdos del Honrado Concejo de la Mesta, libros 507 y 508, y Cuaderno de Leyes de Mesta de 1731, segunda parte, título XV, ley XXI, pp. 159-60.

${ }^{44}$ Cuaderno de Leyes de Mesta de 1731, segunda parte, título XLVIII, p. 251. Explicaba las condiciones y requisitos de los pleitos para ser seguidos y costeados por la Mesta. 
Fermin Marin Barriguete En busca de la justicia: los agentes de corte y chancillerías...

tor de los alcaldes entregadores, imagen paternalista y mano justiciera en el campo ${ }^{45}$.

Incomprensiblemente, el asunto de la disponibilidad de hierbas y la regulación de arrendamientos ${ }^{46}$ no colaboró en el relanzamiento de la figura de los procuradores y sus necesarios servicios ${ }^{47}$. En plena conculcación de la posesión y del hervidero de conflictos en torno a los pastos en subastas, contratos o disfrutes, la Cabaña Real se mostraba incompetente en el uso de los oficios disponibles y no recurrir a la alta magistratura y la Corte, por lo que tenía que pagar el alto precio de pérdida de autonomía. Desbordados y sin respaldo, los procuradores eludieron, en la medida de lo posible, infracciones en cañadas, comunales, penas y prendas o imposiciones $^{48}$, y se centraron, como además exigían los aires que soplaban en las juntas generales, en la validez y mantenimiento de jurisdicción o mercedes. Hasta los cabildos indujeron a los vocales mesteños el rechazo a la actividad procesal. Y más aún influyeron, en la segunda mitad del siglo XVIII, los señores de rebaños, defensores a ultranza de la orientación burocrática de la Mesta, la presencia real y el espontáneo desarrollo de la trashumancia.

La recepción en las chancillerías de las apelaciones de las sentencias de los alcaldes entregadores ${ }^{49}$, la descontrolada concesión de licencias ${ }^{50}$, la hostilidad de los tribunales, la multiplicación de veredictos contrarios o la sordera ante las súplicas de los hermanos dieron argumentos a los partidarios de abandonar las chancillerías como vía reivindicativa y benefactora. De poco servían los agentes en un ambiente tan inapropiado y adverso,

${ }^{45}$ Ibid., primera parte, privilegio III, p. 7; privilegio XV, p. 37, y privilegio XVIII, p. 40. Véase, además, segunda parte, título LII, p. 256.

${ }^{46}$ G. Anes Álvarez de Castrillón, Cultivos, cosechas y pastoreo en la España Moderna, Madrid, Real Academia de la Historia, 1999.

${ }^{47}$ Por esa razón fracasó en la primera mitad del siglo XvIII la legislación generada por el Memorial del Honrado Concejo de la Mesta para reducir los precios de las hierbas y establecer moratorias en el pago de los arrendamientos, 12 de marzo de 1695, AHN, Consejos Suprimidos, leg. 7133.

${ }^{48}$ P. García Martín (coord.), Cañadas, cordeles y veredas, Valladolid, Junta de Castilla y León, 2000.

${ }^{49}$ En esta línea antimesteña y potenciada por la Corona se inserta Real provisión de los Señores del Consejo, en que se aprueba el Auto proveido por el Señor Presidente del honrado Concejo de la Mesta en el próximo de Jadraque, y publicado en la Junta general de 10 de Octubre anterior sobre lo que deben observar los Alcaldes mayores-entregadores de Mesta y Cañadas, todo en la forma que se expresa, 24 de diciembre de 1779, Biblioteca Histórica Marqués de Valdecilla (BHMV), BH DER 19686.

${ }_{50}$ AHN, Diversos, A. de Mesta, leg. 247, exp. 33, o AHN, Consejos Suprimidos, leg. 35307, exp. 3. 
Fermín Marín Barriguete En busca de la justicia: los agentes de corte y chancillerías...

y nunca reconducido por las desidiosas disposiciones reales, papel mojado durante siglos ${ }^{51}$. La sobrecarta de abril de $1719^{52}$ ordenaba a la chancillería de Valladolid el respeto a las sentencias de los alcaldes entregadores y volvía a amenazar en caso de incumplimiento ${ }^{53}$.

\section{LAS SELECTIVAS Y MANIPULADAS COMPETENCIAS}

El talante setecentista arrebató a los agentes de corte y chancillerías la portavocía cabañil. Ya no eran emisarios comisionados a través de los vocales enviados a las juntas, pues se había roto ese vínculo con los ganaderos al transmutarse en oscuros burócratas de una institución en declive e intervenida por la Corona. Alejada de la realidad pecuaria ${ }^{54}$, la Cabaña Real declaró las causas privadas fuera de la jurisdicción de los procuradores. Los pequeños y medianos pastores se consideraron desprotegidos y no representados por un organismo ignorante de sus necesidades y problemas, cúmulo de molestias y contribuciones, y sólo atento a las directrices ilustradas y a los intereses de los señores de rebaños. Las mutaciones agrarias coyunturales habían ido desde la defensa generalizada de la libertad de tránsito en el quinientos, al rechazo de los casos y asuntos considerados concretos, para centrarse en algunos aspectos pastueños, por ejemplo, la posesión, y en los etéreos grandes temas de la trashumancia, como la legislación administrativa interna.

$\mathrm{Al}$ objeto de no acrecentar las fracturas en la sociedad pastoril, no hubo medidas destinadas a delimitar los tipos de pleitos a cargo de los agentes. Por supuesto, fueron apartados de las apelaciones de hermanos al Consejo de Castilla o a las chancillerías, renunciando al papel de árbitros ${ }^{55}$. Únicamente actuaban, con previa licencia, en los seguidos por el Concejo o su presidente por la relevancia ganadera ${ }^{56}$; en sumarios de despojos con

${ }^{51}$ Cuaderno de leyes de Mesta de 1731, primera parte, título III, capítulo VIII, p. 266.

52 Rescataba la legislación emitida al efecto en 1677, 1680, 1689, 1692 y 1693.

53 Acuerdos del Honrado Concejo de la Mesta, libro 513, y Cuaderno de leyes de Mesta de 1731, título LII, cap. IX, pp. 267 y ss.

54 J. P. Díaz López y A. MuÑoz Buendía (coords.), Herbajes, trashumantes y estantes. La ganadería en la Península Ibérica (épocas medieval y moderna), Almería, Instituto de Estudios Almerienses, 2002.

55 Cuaderno de leyes de mesta de 1731, segunda parte, título XLVIII, ley II, p. 251.

56 M. A. Melón JimÉneZ, «La ganadería española en la Edad Moderna. Apuntes para su estudio», en El mundo rural en la España Moderna, Cuenca, Universidad de Castilla-La Mancha, 2004, pp. 727-772. 
Fermin Marin Barriguete En busca de la justicia: los agentes de corte y chancillerías...

dos sentencias positivas ${ }^{57}$, triunfo seguro y fuente de jurisprudencia ${ }^{58}$; en rencillas sobre rentas concejiles o sus arrendamientos, de impacto directo en la hacienda. Los demás litigios tenían la catalogación de particulares y ajenos a la Mesta ${ }^{59}$, de ahí la desocupación de los agentes en las chancillerías. Por acuerdo de 30 de abril de $1712^{60}$ se ratificaba la única dedicación a las causas universales, aunque no sin contradicciones y opacidad ${ }^{61}$. Todavía a principios el siglo XVIII afloraban los ecos de los debates a favor de la resurrección del espíritu y sentido primigenios y de la representatividad alfonsina, porque, de otra forma, resultaba injustificable la jurisdicción absoluta pecuaria reclamada y perseguida. No estaba clara la divisoria entre querellas privadas y cabañiles, pues era más una cuestión de interpretación que una condición intrínseca de las disputas. Cuando contravenían la legislación, a juicio de la junta general y del presidente, se comisionaba a los procuradores y la Mesta asumía la dirección y gastos procesales, mientras que en los pleitos privativos únicamente podrían solicitar asesoramiento legal y no vinculante, e iban a costa del demandante. El Auto de 24 de marzo de 1719 otorgaba la exclusiva potestad al presidente de catalogar y seleccionar los litigios e incluía, sin pudor, la posesión entre las causas universales, a voluntad de los poderosos señores de rebaños ${ }^{62}$. Orgullosa de esas decisiones, la Cabaña Real valoraba muy positiva la redefinición de funciones de los procuradores y el remarcado jurisdiccional, lo que impedía ver algunos de los nocivos efectos, agudizados al extremo a lo largo de la centuria, como el regreso de los ganaderos a la órbita pastoril municipal y a la identificación con las ordenanzas locales, cada vez más pujantes, en contraste con la decepcionante y traicionera Mesta ${ }^{63}$. El siguiente texto recogía la realidad:

${ }^{57}$ Cuaderno de leyes de Mesta de 1731, segunda parte, título X, ley IX, p. 140. El asunto se trató en la junta general de 1517 celebrada en Calatrava y presidida por el Sr. Palacios Rubios.

${ }_{58}$ Ibid., título VI, ley VI, p. 78.

59 Esta postura invalidaba la legislación antecedente. Ibid., adición al título XV, capítulo I, p. 160, y título XLVIII, ley II, p. 251.

${ }_{60}$ Acuerdos del Honrado Concejo de la Mesta, libro 513

${ }^{61}$ Cuaderno de leyes de Mesta de 1731, segunda parte, adición al título XV, capítulo V, p. 160.

${ }_{62}$ Acuerdos del Honrado Concejo de la Mesta, libro 513.

${ }^{63}$ Así se apreciaba en Ordenanzas para el buen gobierno de la Muy Noble y Muy Leal ciudad de Xerez de los Caballeros, 1758; Ordenanzas de la M. N. y M. L. Ciudad de Badajoz... aprobadas por Supremo Consejo de Castilla en 28 de Enero..., Madrid, 1767, y en Ordenanzas hechas por la muy noble y muy leal ciudad de Logroño, con que se rige y govierna el Campo de ella. Confirmadas por S. M. el año de 1539, Francisco Delgado, Logroño, 1744. 
Fermín Marin Barriguete En busca de la justicia: los agentes de corte y chancillerías...

«Que aviendo experimentado muchos inconvenientes en que el Procurador General, sin tener ordenes especiales de las Juntas Generales, ni de los Señores Presidentes, ha salido a diferentes negocios con la voz del Concejo, y que aunque en las dichas Juntas, reconociendo los perjuizios, se ha tratado, y resuelto no salga, si no es con ordenes especiales, no obstante ha salido, por lo que se han acrecentado los perjuizios, e inconvenientes, y crecidos gastos del dicho Concejo [...] debia mandar, y mando, que de aqui adelante el dicho Procurador General, que al presente es, y los que le succedieren solo puedan salir, en nombre del Concejo, a los negocios, que por las Juntas Generales se le encargaren, y pusieren en su instrucción; y en caso de que se ofrezcan negocios de entidad en que se interese el comun de la Cabaña Real, a que les parezca deben salir en los intermedios de las Juntas Generales, tengan obligación de dár quenta a los Señores Presidentes [...] y solo pueda coadyubar a algunos Ganaderos quando se les inquiete en sus possessiones, y pedir algunos despachos para la observancia de las Leyes y Privilegios de la Cabaña Real, sin intrometerse en nuevas pretensiones, ni motivar pleytos: y este mandato [...] se tenga presente en las Juntas Generales» ${ }^{64}$.

Por Acuerdo de 2 de octubre de 1780, con ratificación del Consejo de Castilla, se confirmaba y copiaba la legislación antecedente y se declaraban los casos en que la Cabaña Real coadyuvaba las instancias de los hermanos y asumía la defensa de los pleitos ${ }^{65}$.

\section{LAS DESCARNADAS ATRIBUCIONES DE LA DECADENCIA}

Los procuradores de corte y los agentes de chancillerías acrecentaron su pésima fama a lo largo del setecientos, culpados de mal cumplimiento de sus cometidos. Parecía cierta la idea del mal desempeño de los cargos a la vista de los deficientes resultados, aunque nadie reconocía los destructivos efectos de la parálisis institucional, que hacía impensables reformas o adaptaciones; la continua interferencia de intereses, que enfangaban e invalidaban la legislación o las comisiones, y el fracaso fiscal en las residencias y sanciones. La concentración de trabajo en el procurador de corte reavivó la polémica de la justificación del dinero entregado para las tra-

${ }^{64}$ Cuadernos de leyes de Mesta de 1731, segunda parte, adición al título XV, capítulo III, p. 161.

${ }_{65}$ Acuerdos del Honrado Concejo de la Mesta, libro 519. Véase también M. BRIEVA, Colección de leyes, reales decretos y órdenes, acuerdos y circulares..., op. cit., p. 204. 
mitaciones de los expedientes. Recibían sumas importantes con la recogida de instrucciones y documentos, que administraban con criterio personal fuera de cualquier supervisión, con la condición de depositar cartas de pago en la primera junta general, asentadas a modo de data en la cuenta particular ${ }^{66}$. El hecho de que hubiera confianza secular en los miembros concejiles provocaba una débil o ninguna fiscalización, pues los registros no residenciaban, sino que prevenían demandas de deudas. Hasta el siglo XVIII los procuradores de corte y los agentes de chancillerías se comportaron negligentemente en la presentación de certificaciones, pero los tesoreros fueron mucho más rigurosos y eficaces en las partidas contables, responsables últimos de las omisiones. La mayor parte de las sumas de la procuraduría general iban destinadas a sufragar consultas jurídicas y contratación de abogados colaboradores, prohibidos por diversas normativas, aunque capitales para abarcar las tareas procesales en amparo de los hermanos. Sin embargo, la Mesta no estaba dispuesta a la asunción de esos gastos adicionales, salvo mandamiento expreso, imputados a su costa ${ }^{67}$.

La evidente desconsideración de la Cabaña Real hacia los procuradores, reflejada en los libros de acuerdos, mermó el crédito concedido a su labor y la notoriedad de la jurisprudencia generada, otrora vital. La reorientación del oficio y de sus funciones afectó a los procedimientos, ahora limitados a la salvaguarda de las leyes y privilegios estructurales de los códigos mesteños con el valor de guías, y jamás determinantes frente a la voluntad real o a sus indicaciones, de ahí que los aportes documentales complementarios se calificaban de prescindibles en esta nueva etapa, al igual que demasiados precedentes ${ }^{68}$. Por este motivo, la retirada de legajos y libros del archivo fue casi abandonada, y se portaban sólo los grandes hitos legislativos, en teoría contenedores de la esencia de todas las sentencias y promulgaciones concretas. Los presidentes mandaron la devolución de los papeles sacados en el fundamento de los juicios y trámites, censurando los extravíos u olvidos, además de las ejecutorias y disposiciones resultantes, bajo pérdida de salario ${ }^{69}$.

A la luz de las tormentosas relaciones Mesta-Corona en el setecientos cabría pensar en la existencia de un programa alternativo real en la utili-

${ }^{66}$ Cuadernos de leyes de Mesta de 1731, segunda parte, título XV, ley III, p. 156.

${ }^{67}$ Ibid., título XV, ley XII, p. 158.

${ }^{68}$ Una visión de conjunto la obtenemos del Inventario de las ejecutorias, libros y demás papeles que contiene el archivo del Concejo de la Mesta, 1728, tt. I y II, en AHN, Diversos, A. de Mesta, libros 284 y 285.

${ }_{69}$ Cuaderno de leyes de Mesta de 1731, segunda parte, título XV, ley IV, p. 156. 
zación del sistema ancestral trashumante y la producción de la codiciada lana. Sin embargo, no había otra opción en el campo finisecular y aún se pensaba en la insustituible Cabaña Real, tras una adecuada reforma, para optimizar la trashumancia y garantizar la calidad y aumento del número de fardos en las pilas de los esquileos. La obsesión borbónica por el corrosivo empobrecimiento, que incapacitaba al Honrado Concejo en la asunción y correcta ejecución de las directrices del Trono en el plan de regeneración agraria, condujo a medidas de austeridad y saneamiento con tres claros fines: hacer frente a los gastos ordinarios y reducir los extraordinarios, regular los salarios a la baja y acabar con las pingües ayudas de costa. En este marco se suprimieron de hecho los subalternos temporales ayudantes de los agentes de corte y chancillerías ${ }^{70}$, como letrados o receptores, porque carecían de asignación presupuestaria, y se ordenó a los contadores rechazar las minutas ${ }^{71}$. Todavía más se ralentizó la labor procesal en las convocatorias, aplazamientos o preparación de diligencias, y crecieron invariablemente los juicios perdidos y los despachos fallidos por lagunas de fundamentación, desconocimiento de acuerdos o errores por sobrecarga de trabajo. Lo que se disfrazaba de proteccionismo con vistas a sanear las cuentas ganaderas era, en realidad, un arma mortífera de tradiciones y legislación, ayudada con acusaciones de derroches incontrolados en los debates de las juntas generales de octubre de $1695^{72}$ y mayo de $1705^{73}$.

Con escasa autoridad, sin apenas recursos y en el punto de mira de la institución y de la Corona ante posibles errores, los procuradores dulcificaron procedimientos para lograr mejores resultados. Admitieron pactos con los litigantes, minorar denuncias e indemnizaciones y conseguir veredictos rápidos, sin importar la desproporción con los delitos. La relajación de la tensión y los cortos juicios conllevaban, lógicamente, menos multas y de menor cuantía y protocolarias amonestaciones, que desembocaban en frecuentes reincidencias y sembraban la idea de permisividad en el mundo rural. En el Concejo se cerraron los ojos a la multiplicación de conflictos y la conculcación de los privilegios, a la par que se volvía la cabeza hacia la bienhechora monarquía ${ }^{74}$. Estantes, trashumantes y campesinos aceleraron las rentables infracciones por roturas, reventas de hierbas, prendas o contribuciones, pues los beneficios compensaban las hipotéticas costas judi-

${ }^{70}$ Ibid., ley XIV, p. 158.

${ }^{71}$ Ibid., ley V, p. 156.

72 Acuerdos del Honrado Concejo de la Mesta, libro 512.

${ }^{73}$ Ibid.

${ }^{74}$ Cuaderno de leyes de Mesta de 1731, segunda parte, título XV, ley VII, p. 156. 
Fermin Marin Barriguete En busca de la justicia: los agentes de corte y chancillerías...

ciales. Las avenencias particulares se impusieron en un clima de derrota moral de la Mesta, donde sólo se mantendría la trashumancia a costa de concesiones. La sanción establecida de 50.000 maravedíes a los agentes imputados no disuadía a nadie, persuadidos de la incapacidad ejecutiva cañariega.

La orientación política ganadera y el intervencionismo borbónico aconsejaban la redefinición de atribuciones de los procuradores de corte, habilitados para la solicitud de jueces especiales en causas transcendentales. Aunque muy controlados, la confianza depositada evidenciaba que se habían convertido en los valedores de las prácticas trashumantes al frente de una comitiva de delegados. La puerta de las chancillerías en el siglo XVIII permaneció apenas entreabierta porque ya no era un foro defensivo adecuado de las prerrogativas de paso y pasto cabañiles. De cualquier forma, no tenían carta blanca en nombramientos indiscriminados, pues se necesitaba licencia expresa o se incurría en delito ${ }^{75}$.

No se ignoraba que la procuraduría estaba desbordada por la creciente conflictividad, las apelaciones y los nuevos frentes, lo que originó numerosos debates sobre este asunto y el acuerdo de designación de un segundo agente de corte, con 200 ducados de salario anuales, el 16 de octubre de $1726^{76}$. La junta de apartados ${ }^{77}$ había propuesto al presidente y junta general, dada la cantidad de pleitos pendientes, el desdoblamiento del oficio con la intención de asegurar el rigor procesal y evitar las prolíficas suspensiones $^{78}$. Competía al Consejo de Castilla la ratificación de esta novedad, reflejo de los intereses pecuarios de la Corona y manifestación del cambio de rumbo de la Cabaña Real, que la alejaba un poco más de la realidad trashumante. En principio parecía una iniciativa revolucionaria ilustrada de reforzamiento de la Mesta y prueba fehaciente del papel protagonista otorgado. Al incrementarse la actividad cortesana, sin duda se robustecían las leyes y privilegios. Inexplicablemente, el Acuerdo de 13 de abril de $1739^{79}$ suprimía ese empleo de segundo procurador de corte, disolviendo las expectativas de recuperación cabañera, con las excusas de gravoso e innecesario. Todo apuntaba al irracional plan de restricción de oficialías con el propósito de limitar gastos, coordinado por la organiza-

75 Ibid., ley X, p. 157.

76 Acuerdos del Honrado Concejo de la Mesta, libro 513.

${ }_{77}$ Cuaderno de leyes de Mesta de 1731, segunda parte, título II, pp. 27 y ss.

${ }^{78}$ Ibid., adición al título XV, capítulo VII, p. 164.

79 M. BRIEva, Colección de leyes, reales decretos y órdenes, acuerdos y circulares..., op. cit., p. 47, y Acuerdos del Honrado Concejo de la Mesta, libro 514. 
Fermín Marín Barriguete En busca de la justicia: los agentes de corte y chancillerías...

ción y el Trono e ideado sin mirar hacia el mundo agrario y de irreversibles consecuencias.

Pero lo peor estaba por llegar para los agentes de las chancillerías, arrastrados a la senda agónica del descrédito y el recorte de comisiones y atribuciones ${ }^{80}$. Primero se atacó al de Valladolid con la reducción en dos tercios de salario, de 300 a 100 ducados anuales. Don Fernando de Contreras, Caballero de la Orden de Santiago, secretario real y oficial de la Secretaría de Hacienda, presentó en la junta general de mayo de 1730 la propuesta de abaratar el sueldo. Pretextaba que el peso procesal recaía casi en exclusividad en el procurador de corte y que había muy pocos expedientes en la chancillería y, por ello, resultaba excesivo:

«Por governarse segun la situacion antigua, en que avía crecido numero de litigios; pues consta, que à instancia de este honrado Concejo estaba mandado se viessen en cada semana dos pleitos en difinitiva, de los pertenecientes à èl, siendo assi, que aora escasamente se verifica en un año: que por contrario [...] ha sido preciso nombrar un segundo Agente (en los Tribunales de la Corte)» ${ }^{81}$.

La escasa cuantía percibida con el reajuste comportaba relevar a los ocupantes de Valladolid de asistencia a las juntas generales, salvo motivo especial y compensado con 50 ducados de ayuda de costas. Los 200 ducados restados se aplicaban a pagar el sueldo del segundo agente de corte, gestión loada por muchos, pues había que asignarlos a la asistencia donde más se necesita ${ }^{82}$. La Cabaña Real mantuvo a los agentes de chancillerías en un plano estrictamente burocrático ${ }^{83}$ y prohibió el abono de la notificación de ejecutorias sin permiso expreso, por lo que los afec-

${ }^{80}$ AHN, Diversos, A. de Mesta, leg. 60, exps. 8-9.

${ }^{81}$ Cuaderno de leyes de Mesta de 1731, segunda parte, título XV, capítulo VIII, p. 165.

82 Acuerdos del Honrado Concejo de la Mesta, libro 514

${ }^{83}$ Casos como el siguiente eran la norma. La comarca circundante de Mansilla de las Mulas (León) se caracterizaba por un alto índice de infracciones y los numerosos obstáculos interpuestos a la trashumancia. Los pastores afectados se quejaban en las juntas generales de la ausencia de visitas de los alcaldes entregadores y pedían el envío de jueces especiales. Sin embargo, en este caso no había negligencia por parte de la Cabaña Real porque los alcaldes de corte y chancillería llevaban a los tribunales las denuncias desde 1744 sin efecto alguno. Diez años después se hizo un expediente recopilatorio para dictaminar la falta de exenciones y la conculcación de privilegios. Véase Provisión de los señores del consejo de 1753 en confirmación de otras expedidas aquí insertas contra las justicias de los lugares de Fresno de la Vega, Tabares, Cubillas y otros del Partido de Mansilla de las Mulas para que acudan a residenciarse ante el alcalde mayor entregador de mestas que fuere en el pueblo en donde fije su audiencia, AHN, Diversos, A. de Mesta, leg. 83, exp. 19. 
Fermin Marin Barriguete En busca de la justicia: los agentes de corte y chancillerías...

tados quedaban desinformados de las sentencias definitivas y, casi con seguridad, no se ejecutaban y menos aún se cumplían ${ }^{84}$. Tales antecedentes cimentaron y justificaron el gran descalabro de la segunda medida: la supresión del agente de chancillería de Granada por Acuerdo de 13 de abril de $1739^{85}$.

\section{EL SUSTITUTO: REDEFINICIÓN Y CRISIS EN LA PROCURADURÍA GENERAL DE CORTE}

El pistoletazo de salida de lo que estaba llamado a ser el procurador general de corte en el siglo XviII fue el Auto acordado de 30 de mayo de 1733:

«Mandó que el Procurador del Concejo de la Mesta pueda acudir al Consejo por cualquier de sus escribanías à pedir lo que convenga en nombre de los ganaderos, Hermanos de la Mesta» ${ }^{86}$.

De esta forma se reorientaba la tradición con la comisión particular al oficio y el encargo único de gestionar la voz y el voto de la Cabaña Real con representación universal en las esferas palaciegas ilustradas, bien recabando soluciones y leyes, bien implorando protección regia. Sí, era necesaria tal explicitación porque así se excluía a cualquier otro empleo de las tramitaciones y súplicas, por ejemplo, a los agentes de chancillerías o jueces especiales. Indicativo del nuevo papel y de su naturaleza fue el temprano Auto de 5 de julio de $1717^{87}$, ratificado en el Decreto de 7 de julio de 1731, que salvaba la preeminencia de cubrirse cuando se tratasen pleitos de la Mesta en el Consejo de Castilla y Consejo de Hacienda ${ }^{88}$; con posterioridad se amplió a otros espacios de la administración central ${ }^{89}$.

${ }^{84}$ Cuaderno de leyes de Mesta de 1731, segunda parte, título XV, ley XV, p. 158.

${ }^{85} \mathrm{M}$. BRIEva, Colección de leyes, reales decretos y órdenes, acuerdos y circulares..., op. cit., p. 47, y Acuerdos del Honrado Concejo de la Mesta, libro 514.

${ }_{86}$ M. BRIEVA, Colección de leyes, reales decretos y órdenes, acuerdos y circulares..., op. cit., p. 28, y Nueva Recopilación, libro VII, título XXVII, nota 12.

${ }_{87}$ Cuaderno de leyes de Mesta de 1731, segunda parte, título XV, capítulo VI, p. 163.

${ }^{88} \mathrm{M}$. Brieva, Colección de leyes, reales decretos y órdenes, acuerdos y circulares..., op. cit., p. 4.

${ }^{89}$ Así lo atestiguan los decretos de 1762 y 1774 (ibid., pp. 161 y 193). El decreto de 22 de junio de 1762 se expresaba en los términos siguientes: «Al tiempo de concederse à esta parte la licencia para cubrirse, conforme al privilegio del Concejo de la Mesta, y à la práctica observada con su antecesor Don Manuel Fernandez Salinas, como Procurador general 
Fermín Marín Barriguete En busca de la justicia: los agentes de corte y chancillerías...

Muy significativa de las directrices de la política agraria del Trono, no sorprendió la determinación del Consejo de Castilla de trasladar al procurador de corte los expedientes y solicitudes de aprobación de rompimientos de dehesas despachados para que los contradijese conforme a derecho $y$ leyes del Cuaderno ${ }^{90}$. El Auto acordado de 3 de junio de $1735^{91}$ recogía la preocupación ilustrada de frenar y racionalizar los cultivos de pastizales, posibilitando la conservación de las prácticas trashumantes y las afamadas cabañas productoras de lana de la mejor calidad. Durante décadas, la Corona se encontró en una encrucijada comprometida: por un lado, participaba de la ideología roturadora de ampliación de la superficie sembrada, en especial en la segunda mitad del siglo XviII, y hasta se repartieron términos concejiles con el objetivo de dotar de tierras a los jornaleros y pequeños campesinos ${ }^{92}$; por otro, sabía que la reducción de los herbazales y territorios comunales perjudicaba sobremanera la ganadería estante y trashumante y, por ende, la crianza y actividades económicas aparejadas ${ }^{93}$. La conjunción de ambos pensamientos no parecía tarea fácil y el intento febril de combinación tuvo una gran damnificada: la Cabaña Real ${ }^{94}$, acusada del retraso de la agricultura ${ }^{95}$. En esta ambivalencia permanente, la

del mimo Honrado Concejo, ponga à continuación de este decreto por diligencia la referida licencia».

${ }_{90}$ Nueva Recopilación, libro VII, título XXV, nota 3.

${ }_{91}$ M. BRIEva, Colección de leyes, reales decretos y órdenes, acuerdos y circulares..., op. cit., p. 33.

92 F. SÁnchez Salazar, Extensión de cultivos en España durante el siglo XVIII, Madrid, Ministerio de Agricultura, 1987, e íD., «Los repartos de tierras concejiles en la España del Antiguo Régimen», en G. ANES Álvarez DE CASTRILlÓN (ed.), La economía española al final del Antiguo Régimen. I. Agricultura, Madrid, Alianza Editorial, 1982, pp. 191-258. Véase también T. Pérez Marín, «Repartimientos de baldíos y terrenos montuosos: un medio fallido de resolver el problema extremeño en la segunda mitad del siglo XVIII», Studia Historica. Historia Moderna, núm. 17 (1997), pp. 261-284. De gran interés es Provisión de 29 de noviembre de 1768, extendiendo el repartimiento de tierras de propios y concejiles a todo el Reino, BHMV HIS XVIII-226ESP, y Provisión de su Magestad y Señores de el Consejo en la que se prescriben las reglas que en adelante se han de observar en el repartimiento de pastos, y de las tierras de propios y arbitrios, y concegiles labrantías, 26 de mayo de 1770, BHMV, BH FOA 543(13).

${ }_{93}$ Nos relata el gran número de oficios y trabajos anexos a la trashumancia y ganadería de la Cabaña Real F. A. CAno, Noticia de la Cabaña Real de España, Madrid, 1762, RAH, 9/5992.

${ }_{94}$ M. G. DE JovelLanos, Informe de la Sociedad Económica de esta Corte al Real y Supremo Consejo de Castilla en el expediente de la ley agraria, Madrid, 1795; G. ANEs Álvarez DE Castrillón y A. GarCía SANZ (coords.), Mesta, trashumancia y vida pastoril, Madrid, Junta de Castilla y León, 1994, y G. Anes Álvarez de Castrillón, La Ley Agraria, Madrid, Alianza Editorial, 1995.

${ }_{95}$ T. PÉREZ MARÍn, Don Vicente Paino y Hurtado: defensor de Extremadura en la lucha contra la Mesta, Mérida, Editora Regional de Extremadura, 2000. 
Fermin Marin Barriguete En busca de la justicia: los agentes de corte y chancillerías...

Mesta renacía como el instrumento adecuado con el fin de atajar la desaforada petición y renovación de facultades de labranza ${ }^{96}$ y ajustar la oferta a la demanda con la aplicación de sus leyes y privilegios, y qué mejor comisionado que el procurador general de corte, encumbrado en sus tareas por las íntimas relaciones con la monarquía ${ }^{97}$. Sin embargo, tampoco se cumplió con intensidad suficiente para conseguir el éxito: las notificaciones llegaban tarde a la Mesta; los agentes actuaban con retraso por la sobrecarga de trabajo; los solicitantes rompían incluso antes de la confirmación de las gestiones, confiados en el proclive gobierno; los hermanos, aun conscientes de la importancia y transcendencia del asunto, no querían presionar demasiado y no abanicar conflictos; los señores de rebaños apoyaban el control exhaustivo en las grandes dehesas, pero no en otros lugares; las directrices carolinas no rescindieron estos compromisos, aunque se opusieron. Sobraban las palabras valorativas del patético Auto acordado de 18 de noviembre de 1791, en confirmación del olvidado de 1735, con la consiguiente multiplicación de las labores y la subida de los precios de los pastos por la carestía de las hierbas ${ }^{98}$.

Jefe de gabinete, el procurador de corte disponía con libertad de los recursos institucionales, estaba en contacto con la casi totalidad de los oficios y asumía crecientes responsabilidades. Por este motivo, comenzó a dirigir los pleitos en los grandes arrendamientos y las disputas por jurisdicción a la hora de aplicar la normativa. Las desavenencias con los ganade-

96 Innumerables permisos estaban recogidos en Abecedario general de los privilegios y concordias y otros papeles tocantes al Honrado Concejo de la Mesta, que en virtud de cédulas de S.M. se sacaron de los Reales Archivos de Simancas, y todas las facultades dadas por el Consejo Real de Ordenes y el de Hacienda, para romper dehesas..., y para hacer dehesas, Madrid, 1629, Biblioteca del Ministerio de Hacienda, Madrid, libro 690. Véase también AHN, Diversos, A. de Mesta, leg. 249, exp. 8 a 13.

$97 \mathrm{RAH}, 4 / 1792(3)$, y Autos acordados, antiguos y modernos del Consejo... año de 1723, BN, 3/40928, fol. 127.

98 M. BRIEva, Colección de leyes, reales decretos y órdenes, acuerdos y circulares..., op. cit., p. 78. Por su parte, el Decreto de 2 de septiembre de 1794 ordenaba que no se cobrasen derechos por los escribanos y relatores al procurador general de corte de la Mesta cuando se comunicaban de oficio expedientes sobre roturaciones o de otros asuntos, como era habitual en infinidad de oficios e instituciones. Véanse Provisión de los señores del Consejo, en que por punto general se manda que en el repartimiento anual de las yervas se guarde á los ganaderos en quanto sea posible la costumbre que hayan tenido de acomodar sus ganados, en los terrenos concedidos en anteriores repartimientos, en la conformidad que se expresa, 30 de enero 1788, BHMV BH DER 19948; Real Cédula de S. M. y Señores del Consejo, en que por punto y regla general se concede á los dueños particulares de tierras y arrendatarios, la facultad de que puedan cerrarlas ó cercarlas, para hacer plantios de olivares ó viñas con arbolado, ó huertas de bortaliza con arboles frutales, con lo demas que se expresa, 15 de junio de 1788, BHMV BH DER 18054(38). 
Fermín Marín Barriguete En busca de la justicia: los agentes de corte y chancillerías...

ros de los pueblos colindantes a La Serena derivaron en numerosos procesos y disgustos por el descontrol de las peticiones en varios tribunales por parte del procurador de los reales consejos y de la Cabaña Real. El Acuerdo de 7 de mayo de $1735^{99}$ obligaba a ese procurador de pleitos a disponer de la orden directa de actuación del procurador de corte antes de la puesta en marcha de acciones y pretensiones conducentes a salvaguardar la posesión en Extremadura y otras áreas pastueñas ${ }^{100}$. Al año siguiente, se volvió a insistir sobre la misma cuestión por incumplimiento y perjuicios derivados de los pedimentos contrarios a los intereses cabañiles ${ }^{101}$.

Nada más comenzar el reinado de Carlos III, cuando todavía no se habían perfilado las directrices antimesteñas, hubo colaboración con el procurador de corte, en el marco de la agilización burocrática, y obtuvieron permiso de formulación de cuantas consultas precisasen con escribanos de cámara o relatores en la tramitación de litigios o memoriales. Bien fue verdad que la permisividad se circunscribía a gestiones menores y no significaba en absoluto apertura incondicional o identificación ${ }^{102}$. Después, Campomanes ${ }^{103}$ utilizó el oficio en detrimento de la Cabaña Real al

99 Acuerdos del Honrado Concejo de la Mesta, libro 514.

100 Se cuestionaba constantemente, como se demostraba en A. Díez Navarro, Motivos que expone a la censura del Consejo el Honrado Concejo de la Mesta, en la instancia pendiente, sobre que se declare, que los Particioneros en Dehesas, no deben ni pueden despedirlas, ni desauciarlas a los ganaderos Hermanos de Mesta apossesionados en ellas, con el pretexto de tener los tales Particioneros ganados propios con que pastarlas... 1719, BHMV BH DER 17622(4). Debe consultarse Memorial ajustado, hecho en virtud de auto de El Consejo, à pedimento de las Partes, con citacion y asistencia de ellas... entre el sesmero de la villa y tierra de Cazeres y catorze Vezinos, y Ganaderos Riberiegos de dicha Villa, con Domingo Hidalgo de Torres, Pedro Martinez Fernandez, Matheo Perez, y otros Ganaderos Transhumantes... sobre Deshaucios, y que se declare, que enconformidad de diferentes Executorias (que se referiràn) los Hermanos de Mesta no adquieren possession en las Dehessas de el termino de la Villa de Cazeres, para con los Ganaderos Riberiegos de ella, y que estos, cumplidos los Arrendamientos, que de dichas Dehessas tuvieren hechos los Ganaderos Hermanos de Mesta pueden pujarlas... 1718, BHMV BH DER 17622(17).

101 M. BRIEva, Colección de leyes, reales decretos y órdenes, acuerdos y circulares..., op. cit., pp. 32 y 43 . Se acusó de desobediencia a don Juan Bautista Munilla, que respondió que los acuerdos de la Mesta eran de régimen interno y no vinculantes en el ejercicio de los cargos de los representantes reales.

102 Decreto de 22 de junio de 1762, en ibid., p. 161.

103 P. R. CAMPOMANES, «Idea segura para extender i adoptar en España los conocimientos verdaderos de la agricultura, 1763», Información Comercial Española, ICE: Revista de economía, núm. 512 (1976), pp. 68-74, aquí es donde mejor sintetiza su pensamiento agrario. Véanse también F. Marín BARRiguete, «Campomanes, presidente de la Mesta», en Actas del Congreso Internacional Carlos III y su Siglo, Madrid, UCM, 1990, pp. 93-114; M. BusTos Rodríguez, El pensamiento socioeconómico de Campomanes, Oviedo, Instituto de Estudios Asturianos, 1982; V. Llombart Rosa, Campomanes, economista y político de Carlos III, Madrid, Alianza Editorial, 1992, e íD., «Campomanes, el economista de Carlos III», en 
Fermin Marin Barriguete En busca de la justicia: los agentes de corte y chancillerías...

ordenar que llevase dos libros, uno de todos los ganaderos por partidos para ejecutar la legislación relativa a contribuciones y tasas en mesteños y estantes fuera de la organización, y otro de las cuadrillas ${ }^{104}$. Los recuentos y censos legalizaron el abandono de miles de pastores y cimentaron la desobediencia endémica a las leyes y privilegios durante el resto de la centuria. Por tanto, al ser los portadores documentales, estos agentes acreditaban estar al día en los repartimientos fiscales con el propósito de legitimar la hermandad de aquellos con pretensiones de acudir al Consejo de Castilla o a otro organismo bajo el etéreo manto protector de la Mesta, del que poco quedaba en los años finiseculares. El Acuerdo de 29 de mayo de 1795 contenía lo siguiente ${ }^{105}$ :

«Comuníquese órdenes á todas las Cuadrillas para que hagan saber à sus individuos que toda solicitud de reclamos y demás que aspire à valerse de los privilegios del Honrado Concejo ha de traer puesta nota de la Contaduria ó alcalde de cuadrilla à que estè incorporado de tener satisfechos los pagos del repartimiento antes de presentarle en la escribanía, cuya circunstancia acreditarán también el señor Procurador general cuando solicitasen la nota de ser Hermano para acudir con cualesquier pretensión al Consejo» ${ }^{106}$.

El procurador de corte también había caído por el precipicio de la rutina y decadencia, arrastrado por la agonía concejil.

E. Fuentes Quintana (dir.), Economía y economistas españoles, III. La Ilustración, Madrid, Galaxia Gutenberg-Círculo de Lectores, 2000, pp. 201-255.

104 Acuerdo de 7 de octubre de 1780, en ibid., p. 204.

105 Ibid., p. 264.

106 No se hacía otra cosa más que repetir, casi cincuenta años después, el auto acordado de 13 de marzo de 1753, en ibid., p. 131. 